\title{
An Analysis of Politeness Strategies Used by Male and Female Teachers In EFL Classes In SMP Negeri 4 Kuta Selatan
}

\author{
Km. Dujani ${ }^{1}$, Padmadewi ${ }^{2}$, Asril M. ${ }^{3}$ \\ ${ }^{123}$ English Language Education, Post Graduate Program, Universitas Pendidikan Ganesha, Singaraja \\ e-mail: setia.inggriani@pasca.undiksha.ac.id, agung.marhaeni@pasca.undiksha.ac.id,
}

putu.artini@pasca.undiksha.ac.id

This study aimed at investigating teachers' politeness strategies in two teacher's role which is male and female teacher in EFL classes of the eighth grade students in SMPN 4 Kuta Selatan. The objects of this descriptive qualitative research were utterances delivered by male and female teachers in the classroom activities. This study aimed at finding out (1) describing the types of politeness strategies are used by male English teacher at grade eight of SMPN 4 Kuta Selatan. (2) describing the types of politeness strategies are used by female English teacher (3) explaining the differences in the used of politeness strategies between male and female English teachers. The data were taken from the conversations of the teaching and learning process in the classroom through observation and interviews. The data were gained by observing and video-recording of conversation in classroom discussion and analyzed using politeness strategies by Brown \& Levinson (1987). It was found that the differences strategies used by male and female teacher, the male teacher mostly used bald on record has the highest occurrence (175 times) (16.29\%) expressions, while the female teacher mostly used positive politeness (257 times) (23.93\%) expressions.

\section{Keywords: authentic assessment, Curriculum 2013, discrepancy.}

\section{INTRODUCTION}

Language is a one of essential tools for human life. Language is the most significant possession of human being to do communication and convey their thought, ideas, information, feeling, and so on, from writer to reader, from speaker to listener.

Seken (2007) believes that speaker usually found problem on how to cover or how to utter the ideas to the hearer in a good way and also it can be reserved. In other word, the speaker should have ability in choosing strategy to utter the ideas to the hearer, then it can be accepted well. Thus, learners need knowledge of forms, meanings, and functions. However, they must also use this knowledge by taking into consideration the social situation in other to convey their intended meaning appropriately (Freeman, 2003). People live together in a society and do available conventions or norms in the social context where the politeness as a strategy is used to avoid conflict that might happen and also in order to develop good relationship or togetherness in social interaction. It is very important to speaker uses politeness as a strategy in order to communicate with other members of social community. According to Lakoff (1973), politeness is a strategy used by the speaker to avoid conflict with the hearer. It means that problem can be found in a communication process because of different assumptions, conventions, or others. Moreover, Leech (1983) believes that communication should take care of the togetherness of good relationship. The three experts believe that politeness is a relationship principle or principal of keeping togetherness in a communication in order to avoid offended conflict that might happen.

In contrary, Brown \& Levinson (1987) have a different assumption from those three experts. The assumption is concerned with face saving politeness which comprises a strategy to save the hearer's face by the speaker. The speakers do not want to threat the hearer's face. This theory believes in some case where there are utterances that threat the hearer's face. They also assume that each participant is endowed with what they call face, which is developed into negative face and positive face. One's negative face includes claims to territories, to freedom of action and freedom from imposition. One's positive face involves the needs for social approval, or the want 
to be considered desirable by at least some others. It is based on the presumption that, as part of a strategy for maintaining their own face, the mutual interest of participants in a conversation is to maintain their face from others. In accordance to Face Threatening Acts (FTA), Yule (1996) gives the definition of face. According to Yule, face is the public self-image of a person. It refers to the emotional and social sense of self that everyone has and expects everyone else to recognize. Politeness in interaction can be defined as a means employed to show awareness of another person's face. In this sense, politeness can be accomplished in situation of social distance or closeness.

Yule (1996) further states that within social interaction, people generally behave as if their expectations concerning their public self-image or their face want to be respected. One's face can be categorized into two categorizations: positive face and negative face. Negative face is the basic claim to territories, personal preserves, right to non-distraction, i.e. freedom of action and freedom from imposition, while positive face is a positive consistent self-image or personally (Brown and Levinson, 1987).

The face saving politeness theory has some strategies to save hearer's face from threat. Brown and Levinson's politeness theory (1987) classifies five strategies namely: bald-on-record, positive politeness, negative politeness, off-record, and say nothing. These strategies are hierarchical forms where from the first strategy until the last strategy, the FTA will be decreased.

In English teaching, there are many various ways, such as the present situation and the direction of reformation. No matter where the reformation might go, it doesn't go without teachers' practical work without teachers' language used in the classroom. According to Nunan (1991), teachers' language is of crucial importance, not only for the organization of the classroom, but also for the process of acquisition. Politeness is a common social phenomenon, and is regarded as a moral code in human communication and social activities. As we know, a positive learning atmosphere is encouraging both to teachers and students. Consequently, it is of much importance to know about the extent in which how teachers apply politeness strategy to their language use in EFL classroom. In language study, politeness refers to the ways teachers used language when they converse with their students. In teaching English as a foreign language (EFL), besides having the skills in teaching the language, a teacher also has to learn the way to express the statements in polite way.

Watts (2003) stated that politeness is not something we are born with, but something we have to learn and be socialized into, no generation has been short of teachers and handbooks on etiquette and correct behavior to help us acquire polite skills. It means that politeness is a skill that needs to be learnt. It also needs to be socialized and used in communication because it is important. In English teaching and learning process, politeness is very needed to build students' character that is created through the teacher's polite use of language. Lakoff (1973) pointed out that the general characteristics of a class taught by male teacher are faster-paced, sudden topic shift, and shorter but more frequent sudden turns. He argued that, similarly, female teacher are usually described as communicative facilitators and perhaps more tolerant of first language use. Female teachers are also described as being too forceful in choosing topics and asking too many questions. Lakoff also argued that tag questions and questions generally were more often employed by female speakers. A request such as "want you clean the board?" which is and indirect speech act, is a characteristic of female speech, while "Clean the broad!", a direct speech act is characteristic of male speech. Lakoof further noted that female speech sounds more polite than men's because of the features such as tag questions and the greater indirectness primarily with the intent to smoothen and perpetuate the conversational flow.

Based on situation that politeness is important, the writer will conduct research on politeness strategies. The writer also wants to analyze the politeness strategies used from different gender and in teaching EFL Classes. The setting of the study is in SMP Negeri 4 Kuta Selatan and the subjects are male and female English teachers who teach grade VIII. The English subjects are taught by two teachers, however the teachers do not teach together in one class. It means that the teachers teach in different classes and periods. Related to the above explanation, the title of this research to be: An Analysis of Politeness Strategies Used by Male and Female Teachers in EFL Classes in SMP Negeri 4 Kuta Selatan 
Referring to the condition above, the objectives of this present study were: 1) To describe the types of politeness strategies are used by male English teacher at grade eight of SMPN 4 Kuta Selatan, 2) To describe the types of politeness strategies are used by female English teacher at grade eight of SMPN 4 Kuta Selatan, 3) To explain the differences in the used of politeness strategies between male and female teachers English teacher at grade eight of SMPN 4 Kuta Selatan.

\section{RESEARCH METHOD}

The theory by Brown \& Levinson (1987) was used as the method for this evaluation study. This study aims to find the politeness strategies used by male and female teachers during teaching English in the classroom activities in EFL classroom of SPN 4 Kuta Selatan. Therefore, SMP N 4 Kuta Selatan as a piloting school in Kuta Selatan District was chosen as the setting of this study whiles the male and female English teachers from $8^{\text {th }}$ grade were considered as the subjects of the study.

The instruments used in this present study were interview and observation. The interview was used to know teachers' respond or attitude toward authentic assessment implementation while the observation by recording were used to gathered information about the real implementation done by the teachers. Therefore, the data were collected through document study, class observation, records, and interview. The objects of study were teaching learning process, English teachers and teachers work. Then, the data needed in this research were collected through descriptive qualitative data.

The data were analyzed descriptively. First, in order to be able to find the politeness strategies of the male and female teachers and each difference were calculated. The strategies by each teacher were found by Brown \& Levinson's theory; bald on record, positive politeness, negative politeness, off record and say nothing by seen the data transcription and the classification of the strategies. Then, by using the data transcription and classification of the strategies by the male and female teacher was calculated by using the Ideal Theoretical Reference Criteria. It was analyzed in every type of authentic assessment. In order to figure out how great the discrepancy occurred, the percentile of the discrepancy was calculated. In more specific way, percentile is a number that represents the percentage of scores that a particular raw score exceeds. Therefore, at last to obtain the discrepancy of authentic assessment, it used formula such as discrepancy is the standard score minus the obtained score.

\section{FINDINGS AND DISCUSSION}

Discrepancy of Authentic Assessments in EFL Classroom Based on Curriculum 2013

In order to answer the first research question, the obtained data were presented as follows.

Table 1. Authentic Assessment Implementation in EFL Classrooms of SMAN 8 Denpasar

\begin{tabular}{|c|c|c|c|c|c|c|}
\hline \multirow{2}{*}{$\begin{array}{c}\text { Type of } \\
\text { assessment }\end{array}$} & \multirow{2}{*}{$\begin{array}{c}\text { Standard } \\
(\%)\end{array}$} & \multicolumn{4}{|c|}{ Observed (\%) } & \multirow{2}{*}{$\begin{array}{c}\text { Discrepancy } \\
(\%)\end{array}$} \\
\hline & & $\begin{array}{c}10^{\text {th }} \\
\text { Grade }\end{array}$ & $\begin{array}{l}11^{\text {th }} \\
\text { Grade }\end{array}$ & $\begin{array}{c}12^{\text {th }} \\
\text { Grade }\end{array}$ & Mean & \\
\hline $\begin{array}{c}\text { Self- } \\
\text { assessment }\end{array}$ & 100 & 42.13 & 34.73 & 20.00 & 32.29 & 67.71 \\
\hline $\begin{array}{l}\text { Performance } \\
\text { assessment }\end{array}$ & 100 & 57.46 & 41.17 & 36.72 & 45.12 & 54.88 \\
\hline $\begin{array}{c}\text { Project } \\
\text { assessment }\end{array}$ & 100 & 37.01 & 30.77 & 20.00 & 29.26 & 70.74 \\
\hline $\begin{array}{c}\text { Portfolio } \\
\text { assessment }\end{array}$ & 100 & 20.00 & 31.28 & 20.00 & 23.76 & 76.24 \\
\hline
\end{tabular}

From the table presented, generally it shows that there is a discrepancy occurred between the ideal of authentic assessments implementation based on Curriculum 2013 and the practice in EFL classroom in SMAN 8 Denpasar. The discrepancy occurred in four types of authentic 
assessments. In detail, among those four types of assessment, the biggest discrepancy occurred in portfolio assessment with $76.24 \%$ discrepancy. Then, it was followed by project assessment and self-assessment with their percentile $70.74 \%$ and $67.71 \%$. The lowest discrepancy occurred in performance assessment with $54.88 \%$ discrepancy. Generally, the average discrepancy occurred in authentic assessment implementation in SMAN 8 Denpasar is $67.40 \%$.

In supporting the finding, there was an interview session to the English teachers who implement authentic assessment. The entire English teachers said that the lesson plans used are mostly adopted from teacher training of Curriculum 2013 implementation with limited adjustment to their own students' characteristics. Besides, related into executing of the lesson plan, according the interview and observation, not all of the assessments are implemented in teaching and learning process. Performance assessment was the most used assessment in EFL classroom. Therefore, it shows that there was a misunderstanding from English teachers about authentic assessments implementation that was shown in EFL classroom.

According to the $12^{\text {th }}$ grade teacher, the complexity of portfolio assessment rubric and time consuming were the main obstacle in implementing this kind of assessment. This opinion is supported by Metin (2013) who stated that time limitation become a challenge for teachers in Artvin to implement authentic assessment. Therefore, it is reasonable why portfolio assessment has the widest discrepancy in EFL classroom of SMAN 8 Denpasar.

Based on the research findings, can be concluded various reasons that lead to the big discrepancy occurred in implementing authentic assessment in SMAN 8 Denpasar. Regarding to the findings, those reasons are: 1) insufficient knowledge about the steps of implementing authentic assessment accomplished by the teachers. The steps related to four types of assessment had been assessed for this research, namely: self-assessment, performance assessment, project assessment, and portfolio assessment. 2) lack of teachers' willingness in developing themselves toward authentic assessment. 3) big number of students that lead to time consuming if the teacher implements authentic assessment to assess all of students.

\section{Teachers' Belief on Authentic Assessments Implementation}

The second research question which was about the teachers' belief on authentic assessments implementation was answered by analyzing the questionnaire. Generally, teachers' beliefs on authentic assessment implementation are positive. The English teachers have positive respond toward authentic assessments implementation. It shows from the findings of questionnaire analysis. As explained previously, it divides into seven dimensions which have different total of number. Based on the data analysis, there is no significant different category in every dimension. Therefore, the result of the questionnaire in every dimension shows that: 1) the mastery learning is positive, 2) the authenticity of assessment used is positive, 3) English teachers' understanding toward authentic assessments is positive, 4) the assessment expectation is positive, 5) the curriculum expectation is positive, 6) students' contribution in assessments is moderate, 7) teacher's expectation in relation to authentic assessment implementation in teaching and learning process is positive.

Referring to the findings that has been stated previously, it shows that the English teachers give positive belief of authentic assessments implementation, but there are some problems that found in its implementation that makes the discrepancy occurred. As what stated by Obeita (2011: 1438), "the roles of teacher's beliefs have strongly effect to the successful of teaching and learning process". Moreover, it has significant different between teachers' belief and discrepancy occurred. There are some difficulties that found by the English teachers during authentic assessments implementation. In supporting this finding, there is an interview session to get accurate information.

Based on an interview with the English teachers, it was revealed that most of them know about what authentic assessment is, but they are not sure about how to implement the authentic assessment. Therefore, based on the interview, teachers stated that there are some problems that found by the English teachers in conducting the authentic assessments. The problems is formulates as follows: 1) time allotment, where English as compulsory subject only have 2 hours or 1 meeting in a week, it is not quite enough to be focus on assessing students, 2) class 
condition, the total of students in a class sometimes makes the teachers get confused to assess students, 3) limited supporting tools, for example in portfolio assessment where the teachers must be collects students work and keep it in folder, furthermore, there is folder or maps and certain place to keep students work, 4) students motivation, students who have low motivation sometimes give negative contribution into authentic assessments implementation.

Therefore, those research finding is in line with research study that conducted by Bordoh et al. in 2015, where the finding shows that authentic assessment use in the Social Studies classroom was limited by policy systems, time, resources and assessment methods employed by the various schools. As what explained previously, it needs certain respond from the government to solve this education problem. Therefore, it is related to research study that conducted by Charoenchai, Phuseeorn and Phengsawat (2015) where the aim of this present study is to create teachers development model and evaluate effectiveness of teachers' development model. The finding shows that evaluation of effectiveness of teachers' development model to authentic assessment by empowerment evaluation approach found the model have utility, feasibility, accuracy, propriety and high teachers' satisfaction. Besides, research study which conducted by Azim and Khan (2012) about authentic assessment as a learning tool in a school the context of Pakistan shows that there are desirable changes in the perception as well as practices of teachers and students and considerable improvement in high order skills of the students. To sum up, the importance of authentic assessment implementation must be constructed. It can be done by holding training program to the English teacher about authentic assessment that focus on how to implement it especially in three stages: planning, executing, and analysis and reporting.

\section{CONCLUSION AND SUGGESTIONS}

Based on the data analysis of authentic assessment implementation, shows that discrepancy occurs in four types of it implementation in three different grades in SMAN 8 Denpasar. Based on data analysis can be concluded that the discrepancies in each assessment were: 1$)$ very big $(67.71 \%)$ for self-assessment implementation, 2$)$ very big $(54.88 \%)$ for project assessment implementation, 3 ) big (70.74\%) for performance assessment implementation, and 4) very big (76.24\%) for portfolio assessment. Generally, $67.40 \%$ discrepancy occurred among those four types of assessment. Thus, it concludes that there is a discrepancy occurs between the ideal of authentic assessments implementation based on Curriculum 2013 and the practice of authentic assessment implementation in EFL classroom of SMAN 8 Denpasar. The big discrepancy occurred was in contrast with teachers' belief toward authentic assessment implementation. Among nine indicators, one indicator assumes that teachers have very positive belief toward authentic assessment based on Curriculum 2013, six indicators indicate teachers' positive belief, and only one indicator indicates moderate belief from the teachers. The result of questionnaire shows that the English teachers give positive respond for dimension of mastery learning, assessment authenticity, teachers' understanding toward authentic assessment, assessment expectation, curriculum expectation and teachers' expectation, then moderate respond for students' contribution in assessment. In addition, it generally indicates that English teachers give positive respond on authentic implementation especially in EFL classroom.

Concerning the reasons that has been stated previously, some recommendations can be offered the last stage of discrepancy model. These following recommendations are offered in order to minimalize the discrepancy and help the teachers to implement authentic assessment as close as the required standards that are stated in Permendikbud Number $81 \mathrm{~A}$ year 2013. The first recommendation is addressed to the teachers, the teachers are expected to use the lesson plans that had been provided by the group discussion with caution. Specifically, the lesson plans can be adjusted based on the students; need and characteristic so that the lesson plan be implemented properly in the classroom. The second recommendation is addressed to school management. Seeing the teacher's eagerness to learn, the researcher assumes that more sharing session as well as English teachers group discussion assisted by expert in authentic assessment is strongly needed in order to maximize the teacher's willingness to learn more about the implementation of authentic assessment. 
Moreover, it is recommended for the policy makers to give immediate respond to find out the solution of discrepancy occurred of authentic assessment implementation in EFL classroom of senior high school. It can be done through conducting curriculum training or workshop to the English teachers. The curriculum training or workshop should be arranged based on teachers' need. Therefore, authentic assessment implementation based on Curriculum 2013 as approach of educational goal can be achieved.

It is recommended for other researcher who are interested to conduct similar evaluation research about discrepancy of authentic assessment implementation. This present study analyzed the discrepancy occurred based on authentic assessment as what expected on Curriculum 2013 as standard and authentic assessment that expected in teaching and learning process. Thus, the other researchers are expected to find out the discrepancy of authentic assessment implementation in more specific elements or in different level of study.

\section{REFERENCES}

Bordoh, Anthony., Eshun, I., Quarshie, A. M., Bassaw, T. W., Kwarteng, P. (2015). Social Studies Teachers' Knowledge Base in Authentic Assessment in Selected Senior High Schools in the Central Region of Ghana. Journal of Social Sciences and Humanities, 1(3), 249-257.

Kementrian Pendidikan dan Kebudayaan. (2012). Bahan Uji Publik Kurikulum. Republik Indonesia: Kementrian Pendidikan dan Kebudayaan.

Marhaeni, A. A. I. N. (2005). Self-assessment in EFL instruction: Why does it matter?. Ganesha University of Education (Undiksha) Singaraja- Bali. Retrieved from: http://pasca.undiksha.ac.id/e-learning/staff/images/img_info/4/17-282.pdf.

Marhaeni, A.A.I.N. (2007). Portfolio Assessment, Achievement Motivation and English Writing Ability: An Experimental Research Report. Jurnal pendidikan dan pengajaran UNDIKSHA 4(x). $872-888$.

Marhaeni, A.A.I.N. (2010). Pembelajaran Bahasa yang Bermakna. Orasi IImiah Pengenalan Guru Besar Tetap. Universitas Pendidikan Ganesha.

Marhaeni, A.A.I.N. (2012). Evaluasi Program Pendidikan: Buku Ajar Mahasiswa Program Pasca Sarjana. Universitas Pendidikan Ganesha: Singaraja.

Marhaeni, A.A.I.N. (2013). Pengembangan Perangkat Asesmen Autentik sebagai Asesmen Proses dan Produk dalam Implementasi Kurikulum Tingkat Satuan Pendidikan (KTSP) Mata Pelajaran Bahasa Inggris di SMP Provinsi Bali. Laporan Penelitian Tim Pascasarjana Tahun I.

Marhaeni, A.A.I.N., Artini, L. P. (2015) Asesmen Autentik dan Pendidikan Bermakna: Implementasi Kurikulum 2013. Program Studi Pendidikan Bahasa Inggris, 4(1). 499-511.

Metin, M. (2013). Teachers' Difficulties in Preparation and Implementation of Performance Task. Educational Sciences: Theory \& Practice, 13(3), 1664-1673. DOI: 10.12738/estp.2013.3.1452.

Padmadewi, N. N. (2014). Asesmen Kurikulum. Singaraja: Graha IImu.

Paragae, I., Marhaeni, A., \& Dantes, N. (2013). Teacher Made Assessment Authenticity in Senior high schooland Its Contribution to Students' English Achievemnt. e-Journal Program Pascasarjana Universitas Pendidikan Ganesha Program Studi Pendidikan Bahasa Inggris.

Permendikbud No. 103 Tahun 2014 tentang Pembelajaran pada Pendidikan Dasar dan Pendidikan Menengah.

Permendikbud No. 104 Tahun 2014 tentang Penilaian Hasil Belajar oleh Pendidik Pada Pendidikan Dasar Dan Pendidikan Menengah.

Permendikbud No. 53 Tahun 2015 tentang Penilaian Hasil Belajar oleh Pendidik dan Satuan Pendidikan pada Pendidikan Dasar dan Pendidikan Menengah.

Permendikbud No. 70 Tahun 2013 tentang Kerangka Dasar dan Struktur Kurikulum Sekolah Menengah Kejuruan/Madrasah Aliyah Kejuruan dengan Rahmat Tuhan Yang Maha Esa Menteri Pendidikan dan Kebudayaan Republik Indonesia. 
Permendikbud No. 81a Tahun 2013 Tentang Implementasi Kurikulum Dengan Rahmat Tuhan Yang Maha Esa Menteri Pendidikan Dan Kebudayaan Republik Indonesia.

Sahiruddin. (2013). The Implementation of the 2013 curriculum and the issues of English language teaching and learning Indonesia. The Asian Conference on Language Learning 2013: Official Conference Proceedings: Osaka, Japan. 